\title{
Kinerja Karyawan Berdasarkan Keterbukaan terhadap Pengalaman, Organizational Citizenship Behavior dan Budaya Organisasi
}

\author{
Pratista Arya Satwika ${ }^{1}$ Fathul Himam ${ }^{2}$ \\ Fakultas Psikologi Univeritas Gadjah Mada
}

\begin{abstract}
Globalization era demands high organization's performance to survive. There are some human resource problems in Indonesia that indirectly influence individuals' performance in the organization. This research aimed to determine openness to experience, organizational citizenship behavior (OCB) and employee-oriented organizational culture as employee performance predictor. Ths was a field study that used a quantitative methodology. A questionnaire was used to collect data about openness to experience, organizational citizenship behavior, employee-oriented organizational culture, and employee performance. Hypothesis test done with regression analysis toward 166 respondents resulted in the value of $F=52,971(p<0.05)$. Data analysis results explained that openness to experience variable, organizational citizenship behavior variable, employee-oriented organizational culture variable worked together to give influential contribution as much as $49.5 \%$ toward employee's performance. The study resolved that the organizational citizenship behavior and openness to experience are significant variables for predicting employee performance.
\end{abstract}

Keywords: openness to experience, organizational citizenship behavior, organization's culture oriented to employees, employee performance

\begin{abstract}
Abstrak. Era globalisasi saat ini menuntut kinerja organisasi yang tinggi untuk dapat bertahan. Banyaknya permasalahan tentang SDM di Indonesia secara tidak langsung memengaruhi kinerja individu dalam organisasi. Penelitian ini bertujuan untuk menguji keterbukaan terhadap pengalaman, organizational citizenship behavior (OCB) dan budaya organisasi berorientasi pada karyawan sebagai prediktor dari kinerja karyawan. Penelitian ini merupakan studi lapangan menggunakan metodologi kuantitatif. Kuesioner yang digunakan adalah kuesioner keterbukaan terhadap pengalaman, organizational citizenship behavior, budaya organisasi berorientasi pada karyawan dan kinerja karyawan. Uji hipotesis dilakukan dengan $\mathrm{n}$ analisis regresi terhadap 166 responden menghasilkan nilai $F=52,971 \quad(p<0,05)$. Hasil analisis data menyatakan bahwa variabel keterbukaan terhadap pengalaman, OCB dan budaya organisasi berorientasi terhadap karyawan secara bersama sama memberikan kontribusi sebesar 49,5\% terhadap kinerja karyawan. Implikasinya bahwa variabel OCB dan keterbukaan terhadap pengalaman layak untuk dipertimbangkan dalam memprediksi kinerja karyawan.
\end{abstract}

Kata kunci: keterbukaan terhadap pengalaman, organizational citizenship behavior, budaya organisasi berorientasi pada karyawan, kinerja karyawan

Era globalisasi saat ini menuntut kinerja organisasi yang tinggi untuk dapat

\footnotetext{
${ }^{1}$ Korespondensi mengenai isi artikel ini dapat dilakukan melalui: pratista.arsat@gmail.com

22Atau melalui: fhimam@ugm.ac.id
}

bertahan hidup ditengah-tengah tingkat persaingan yang sangat ketat antar organisasi. Pada saat ini organisasi dituntut untuk tidak hanya bersaing dengan sesama organisasi dalam negeri, tapi juga dengan organisasi atau perusahaan multinasional 
dari luar negeri. Hal ini diperkuat dengan adanya kesepakatan perdagangan bebas, baik regional maupun dunia seperti Asean Free Trade Area (AFTA) dimana Indonesia merupakan salah satu negara yang ikut serta didalamnya. Sementara itu terdapat sejumlah fakta yang menunjukkan bahwa daya saing bangsa Indonesia saat ini mengalami penurunan dimana dari hasil survei The Global Competitiveness Report 2011-2012 terbitan World Economic Forum (WEF) tentang peringkat daya saing melaporkan bahwa peringkat Indonesia turun dua peringkat dari 44 menjadi 46 pada 2010-2011 (Schwab, Martin, \& Greenhill, 2011). Dari dimensi lain tentang Indeks Pembangunan Manusia (IPM) tahun 2010, Indonesia berada pada rangking 108 dari 169 negara dan termasuk dalam kelompok Medium Human Development (Human Development Report 2010 team, 2010).

Penurunan kualitas karyawan selama beberapa tahun terakhir ini membuktikan bahwa bangsa Indonesia belum benarbenar siap untuk menghadapi perubahan secara global. Karyawan merupakan unsur terpenting dalam sebuah organisasi, penurunan kualitas karyawan sangat memengaruhi kemajuan dan kemunduran organisasi, hal ini dikarenakan karyawan merupakan penggerak organisasi. Oleh karena itu, penting untuk mengetahui bagaimana seseorang bekerja dan apa saja yang memengaruhinya untuk menghasilkan kinerja yang optimal. Beberapa perilaku yang sering dilakukan karyawan saat bekerja misalnya masih banyak pegawai yang cenderung menganggur dan tidak mengerjakan tugas sebagaimana mestinya sesuai dengan waktu yang diberikan, tidak mau bekerjasama dengan karyawan lain, kurang persiapan untuk menghadapi rapat maupun presentasi, sering datang terlambat dan absen, tidak bersedia dan sering mengeluh bila harus bekerja lebih lama dari waktu yang seharusnya, serta kurangnya usaha untuk menampilkan kinerja yang terbaik (Manopol \& Banirestu, 2011).

Dalam dunia bisnis, kinerja individu sangat memengaruhi kinerja perusahaan, namun tidak semua pengelola perusahaan sungguh-sungguh mengerti bagaimana mengelola sumber daya manusia/karyawan secara tepat sehingga karyawan benar-benar memberikan kontribusi yang efektif bagi perusahaan. Penelitian ini ingin melihat kinerja sebagai perilaku individu yang relevan dengan tujuan organisasi, sehingga dalam penelitian ini peneliti menggunakan pengukuran subjektif untuk mengukur kinerja karyawan. Kinerja merupakan kombinasi antara kemampuan dan sifat (ability and traits), usaha (effort) dan dukungan (support) yang diukur melalui hasil produksi atau hasil kerja yang telah dicapai oleh seseorang (Bernadin \& Russel, 1998; Klehe \& Anderson, 2007; Kreitner \& Kinicki, 2010; Steers \& Porter, 1983).

Penelitian tentang kinerja banyak dilakukan dan masih sangat bervariasi salah satunya menyatakan bahwa kinerja berkorelasi positif dengan beberapa variabel penting, yaitu kepribadian (Barrick \& Mount, 1991; Burmana, 2010; Rose, Ramalu, Uli, \& Kumar, 2010; Skyrme, Wilkinson, Abraham, \& Morrison, 2005), kecerdasan emosional, kepuasan kerja (Ali, Hayat, Sarwat, \& Qureshi, 2011; Thomas, Susanna, \& O'Hara, 2006), kepercayaan karyawan, locus of control, pemberdayaan karyawan (Rahman, 2009), organizational citizenship behavior (Bommer, Dierdorff, \& Rubbin, 2007; Khan, Afzal, \& Zia, 2010), keterlibatan kerja (Biswas, 2011), kepercayaan pada supervisor (Chen, Tsui, \& Farh, 2002), komitmen kerja (Ali dkk., 2011), organisasi pembelajar (Tahir, Naeem, Sarfraz, Javed, \& Ali, 2011), kea- 
dilan organisasi (Khan, Mukhtar, \& Niazi, 2010), kemampuan, motivasi kerja dan persepsi peran (Pentury, 2010). Robbins dan Judge (2008) menjelaskan beberapa karakteristik biografik yang dapat memengaruhi kinerja yaitu, umur, jenis kelamin dan jabatan.

Penelitian ini membahas lebih lanjut tentang kinerja karyawan agar dikemudian hari dapat dijadikan sebagai sumber referensi untuk meningkatkan kinerja karyawan. Karyawan akan dapat bekerja dengan baik jika memiliki kemampuan, keterampilan dan karakteristik personal yang dituntut dan relevan dengan kebutuhan organisasi. Kinerja karyawan juga ditentukan oleh seberapa besar motivasi karyawan dalam usaha mencapai standar yang ditetapkan organisasi. Selain usaha dan kemampuan serta sifat individu, dukungan dari lingkungan juga diperlukan untuk memperkuat perilaku kerja. Dukungan tersebut dapat berupa dukungan secara manajemen ataupun dukungan langsung dari atasan atau supervisor yang dibentuk oleh lingkungan organisasi. Tujuan penelitian ini adalah untuk menguji keterbukaan terhadap pengalaman, organizational citizenship behavior (OCB) dan budaya organisasi berorientasi karyawan sebagai prediktor dari kinerja karyawan.

Penelitian yang menggunakan kepribadian untuk memprediksi kinerja telah menunjukkan bahwa diantara kelima faktor dari big five, keterbukaan terhadap pengalaman menghasilkan korelasi hubungan yang paling rendah dengan kinerja (Barrick \& Mount, 1991; Griffin \& Hesketh, 2004). Sedangkan Rose dan kawan-kawan (2010) dalam penelitiannya menemukan bahwa keterbukaan terhadap pengalaman adalah ciri kepribadian satusatunya yang secara signifikan berkaitan dengan semua dimensi kinerja kerja ekspatriat. Berdasarkan hal tersebut maka diperlukan penelitian lebih lanjut untuk membuktikan hubungan antara keterbukaan terhadap pengalaman terhadap kinerja karyawan serta bagaimana pengaruhnya terhadap kinerja karyawan.

Disamping itu, selain kemampuan dan sifat yang dalam penelitian ini diwakili oleh kepribadian keterbukaan terhadap pengalaman, usaha (effort) juga merupakan faktor yang tidak kalah penting dalam memengaruhi kinerja karyawan. OCB adalah sikap membantu yang ditunjukkan oleh anggota organisasi, yang sifatnya konstruktif, dihargai oleh perusahaan tapi tidak secara langsung berhubungan dengan produktivitas individu. Penelitian Khan dan kawan-kawan (2010) menemukan bahwa anteseden OCB memiliki hubungan positif dengan kinerja organisasi. Selain itu, Chahal dan Mehta (2010) mengemukakan bahwa OCB dapat memberi efek positif terhadap kinerja organisasi misalnya mengurangi ketidakhadiran, turnover, stres psikologis, retensi karyawan serta meningkatkan loyalitas dan kepuasan karyawan dan konsumen.

Menurut Robbins dan Judge (2008) salah satu faktor yang memengaruhi peningkatan kinerja karyawan adalah budaya organisasi. Budaya organisasi yang digunakan dalam penelitian ini adalah tipe budaya employee oriented vs job oriented. Organisasi yang berorientasi terhadap karyawan akan menghasilkan karyawan yang lebih dihargai, sejahtera dan loyal terhadap perusahaan sehingga memiliki keterikatan dengan organisasi dan ikut mendukung serta berpartisipasi terhadap pencapaian kemajuan organisasi. Dalam konteks organisasi, karyawan sejak direkrut selalu dituntut untuk memberikan kinerja yang maksimal bagi perusahaan demi keuntungan bisnis, untuk itu manajemen selalu mencari orang-orang potensial yang memiliki karakteristik 
individu dan kemauan atau usaha untuk berperilaku dan bekerja lebih baik (lihat Gambar 1).

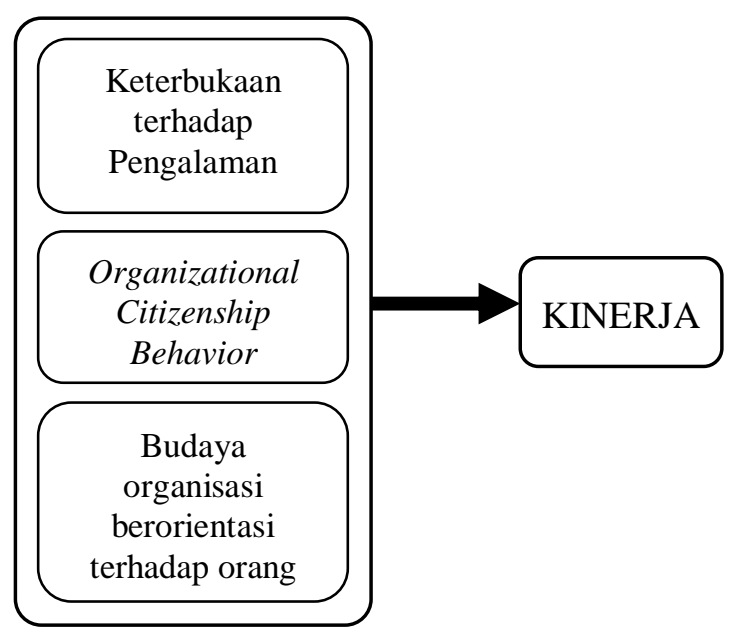

Gambar 1. Kerangka Penelitian

Hipotesis penelitian ini yaitu keterbukaan terhadap pengalaman, OCB, dan budaya organisasi berorientasi karyawan merupakan prediktor dari kinerja karyawan.

\section{Metode}

Penelitian ini melibatkan empat variabel yaitu kinerja karyawan sebagai kriterium dan keterbukaan terhadap pengalaman, OCB, serta budaya organisasi berorientasi karyawan sebagai prediktor. Kinerja merupakan perilaku individu yang relevan dengan tujuan organisasi, yang menghasilkan atau menurunkan efektivitas organisasi dari suatu posisi, khususnya berupa perilaku penyelesaian tugas sesuai peran yang dirinci dalam deskripsi jabatan (Borman, 1991; Cascio \& Aguinis, 2005). Individu yang memiliki kepribadian keterbukaan terhadap pengalaman (openness to experience) adalah pribadi yang sangat terbuka cenderung kreatif, ingin tahu dan sensitif terhadap hal-hal yang bersifat seni. Sebaliknya, mereka yang tidak terbuka cenderung memiliki sifat konvensional dan merasa nyaman dengan hal-hal yang telah ada (McCrae \& Costa, 2003; Robbins \& Judge, 2008).

OCB adalah sikap membantu yang ditunjukkan oleh anggota organisasi, yang sifatnya konstruktif, dihargai oleh perusahaan tapi tidak secara langsung berhubungan dengan produktivitas individu (Organ, Podsakoff, \& MacKenzie, 2006). Budaya organisasi berorientasi terhadap karyawan merupakan lingkungan organisasi yang dipenuhi oleh para pekerja yang menginginkan agar pihak organisasi terlebih dahulu memperhatikan kepentingankepentingan mereka sebelum berorientasi pada pekerjaan yang harus dilakukan (Hofstede, Hofstede, \& Minkov, 2010).

Subjek penelitian adalah 166 karyawan dengan karakteristik sebagai berikut: (1) Berjenis kelamin laki-laki dan perempuan, (2) Masih aktif sebagai karyawan perusahaan ' $\mathbf{X}$ ', (3) Pendidikan terakhir minimal setingkat SMU atau sederajat, dan (4) Memiliki masa kerja minimal satu tahun.

Pengambilan sampel dalam penelitian ini menggunakan jenis sampel nonprobabilitas, teknik pengambilan sampel ini tidak memberikan peluang atau kesempatan yang sama bagi setiap unsur atau anggota populasi untuk dipilih menjadi sampel (Kerlinger, 2000; Sugiyono, 2011).

Penelitian ini merupakan studi lapangan yang menggunakan pendekatan penelitian kuantitatif dengan empat kuesioner sebagai alat pengumpul data, yaitu kuesioner kinerja individu, keterbukaan pengalaman, OCB dan budaya organisasi berorientasi karyawan. Kinerja individu diukur dengan kuesioner kinerja berdasarkan aspek task proficiency dan interpersonal impact (Bernardin \& Russel, 1998; Coole, 2003). Pengukuran keterbukaan terhadap pengalaman disusun dengan kuesioner yang mengacu pada aspek-aspek ideas, 
fantasy, aesthetics, actions, feelings dan values (McCrae \& Costa, 2003).

Pengukuran variabel OCB dilakukan dengan menggunakan kuesioner alat ukur OCB yang disusun dengan mengacu pada aspek-aspek yaitu altruism, courtesy, sportsmanship, civic virtue, dan conscientiousness (Organ dkk., 2006). Pengukuran budaya organisasi dilakukan dengan menggunakan kuesioner alat ukur budaya organisasi yang disusun berdasarkan aspek-aspek dari Hofstede (Hofstede dkk., 2010) yaitu organisasi menghargai gagasan setiap karyawan, perhatian organisasi terhadap kepentingan pribadi karyawan, rasa saling percaya antara karyawan dan organisasi.

Aspek-aspek tersebut diterjemahkan kedalam aitem-aitem pernyataan dengan menggunakan pola Likert. Skala-skala Likert memberikan respons yang sudah dinilai pada tiap pernyataan. Respons tersebut diungkap dalam lima kategori, yaitu sangat sesuai (SS), sesuai (S), netral (N), tidak setuju (TS) dan sangat tidak setuju (STS) (Anastasi \& Urbina, 1997).

Analisis data yang digunakan untuk menguji hipotesis penelitian ini adalah teknik analisis regresi berganda dengan bantuan Program SPSS for windows.

\section{H a $\mathrm{s}$ i 1}

\section{Reliabilitas dan Validitas}

Penelitian ini menggunakan empat kuesioner penelitian, yaitu kuesioner ki- nerja karyawan dengan koefisien reliabilitas alpha sebesar 0,802 dengan rentang indeks daya diskriminasi aitem bergerak antara 0,317 sampai 0,699. Kuesioner keterbukaan terhadap pengalaman dengan koefisien reliabilitas alpha sebesar 0,884 dengan rentang indeks daya diskriminasi aitem bergerak antara 0,327 sampai 0,716. Kuesioner OCB dengan koefisien reliabilitas alpha sebesar 0,884 dengan rentang indeks daya diskriminasi aitem bergerak antara 0,382 sampai 0,752. Terakhir, kuesioner budaya organisasi berorientasi terhadap karyawan dengan koefisien reliabilitas alpha sebesar 0,883 dengan rentang indeks daya diskriminasi aitem bergerak antara 0,355 sampai 0,788 (lihat Tabel 1).

\section{Uji Asumsi}

Uji Normalitas. Hasil uji normalitas pada data kinerja karyawan diperoleh nilai K-SZ sebesar 0,958 dan signifikansi sebesar 0,318, pada data keterbukaan terhadap pengalaman diperoleh nilai K-SZ sebesar 0,868 dengan signifikansi sebesar 0,438, pada dataOCB diperoleh nilai K-SZ sebesar 0,710 dengan signifikansi sebesar 0,695 , sedangkan pada data budaya organisasi beorientasi karyawan diperoleh nilai K-SZ sebesar 0,799 dengan signifikansi sebesar 0,545. Hal ini menunjukkan bahwa keempat data tersebut mempunyai sebaran normal $(p>0,05)$ (lihat Tabel 2).

Tabel 1

Reliabilitas Kuesioner

\begin{tabular}{lcc}
\hline \multicolumn{1}{c}{ Variabel } & $\begin{array}{c}\text { Koefisien } \\
\text { Alpha }\end{array}$ & $\begin{array}{c}\text { Indeks Daya } \\
\text { Diskriminasi }\end{array}$ \\
\hline Kinerja Karyawan & 0,802 & $0,317-0,699$ \\
Keterbukaan terhadap Pengalaman & 0,884 & $0,327-0,716$ \\
OCB & 0,884 & $0,382-0752$ \\
Budaya Organisasi berorientasi terhadap karyawan & 0,883 & $0,355-0,788$ \\
\hline
\end{tabular}


Tabel 2

Hasil Uji Normalitas

\begin{tabular}{lccc}
\hline \multicolumn{1}{c}{ Variabel } & K-S-Z & P & Keterangan \\
\hline Kinerja Karyawan & 0,958 & 0,318 & Normal \\
Keterbukaan terhadap Pengalaman & 0,868 & 0,438 & Normal \\
OCB & 0,710 & 0,695 & Normal \\
Budaya Organisasi berorientasi Karyawan & 0,799 & 0,545 & Normal \\
\hline
\end{tabular}

Uji Linieritas. Hasil uji linieritas diperoleh bahwa hubungan antara variabel kinerja karyawan dengan variabel keterbukaan terhadap pengalaman memiliki nilai $F$ sebesar 63,937 dengan $p$ sebesar 0,001 , dengan variable OCB menghasilkan nilai $F$ sebesar 127,018 dengan $p$ sebesar 0,001 dan dengan variabel budaya organisasi berorientasi terhadap karyawan menghasilkan nilai $F$ sebesar 17,358 dengan nilai $p$ sebesar 0,001 . Hal ini menunjukkan bahwa hubungan keempat data tersebut membentuk data linier $(p<0,05)$ (lihat Tabel 3).

Uji Multikolinieritas. Hasil uji multikolinieritas menunjukkan bahwa ketiga variabel dalam penelitian ini memenuhi syarat dengan nilai tolerance dan VIF masing masing $(\mathrm{VIF}<10)$, yaitu keterbukaan terhadap pengalaman menghasilkan nilai tolerance sebesar 0,707 dengan VIF sebesar 1,415, OCB menghasilkan nilai tolerance sebesar 0,620 dengan VIF sebesar
1,612 dan variabel budaya organisasi berorientasi terhadap karyawan menghasilkan nilai tolerance sebesar 0,849 dengan VIF sebesar 1,178 (lihat Tabel 4).

\section{Uji Hipotesis}

Hasil analisis regresi menunjukkan nilai $R$ sebesar 0,704 dengan nilai $R^{2}$ sebesar 0,495. Selain itu, diketahui pula bahwa secara bersama-sama variabel keterbukaan terhadap pengalaman, OCB dan budaya organisasi berorientasi karyawan memberikan kontribusi sebesar $49,5 \%$ terhadap kinerja. Analisis regresi menemukan nilai $F$ sebesar 52,971 dengan signifikansi 0,001, yang berarti bahwa ketiga variabel secara bersama sama memberikan peranan yang signifikan terhadap kinerja karyawan (lihat Tabel 5). Berdasarkan hal tersebut maka hipotesis yang berbunyi "keterbukaan terhadap pengalaman dan OCB merupakan prediktor dari kinerja karyawan" diterima.

Tabel 3

Hasil Uji Linieritas

\begin{tabular}{lccc}
\hline \multicolumn{1}{c}{ Variabel } & F & $\mathbf{P}$ & Keterangan \\
\hline Kinerja * Keterbukaan terhadap Pengalaman & 63,937 & 0,001 & Linear \\
Kinerja * OCB & 127,018 & 0,001 & Linear \\
Kinerja * Budaya Organisasi berorientasi & 17,358 & 0,001 & Linear \\
Karyawan & & & \\
\hline
\end{tabular}

Tabel 4

Hasil Uji Multikolinieritas

\begin{tabular}{lccc}
\hline Variabel & Tolerance & VIF & Keterangan \\
\hline Keterbukaan terhadap Pengalaman & 0,707 & 1,415 & Memenuhi Syarat \\
OCB & 0,620 & 1,612 & Memenuhi Syarat \\
Budaya Organisasi berorientasi Karyawan & 0,849 & 1,178 & Memenuhi Syarat \\
\hline
\end{tabular}


Tabel 5

Hasil Analisis Regresi Penelitian

\begin{tabular}{ccccc}
\hline Model & $\boldsymbol{R}$ & $\boldsymbol{R}$ Square & $\boldsymbol{F}$ & Sig. \\
\hline 1 &, 704 &, 495 & 52,971 &, 001 \\
\hline
\end{tabular}

Tingkat kinerja karyawan dapat diprediksi melalui besarnya nilai keterbukaan terhadap pengalaman, OCB dan budaya organisasi berorientasi karyawan. Semakin tinggi nilai keterbukaan terhadap pengalaman, OCB dan budaya organisasi berorientasi karyawan maka semakin tinggi pula tingkat kinerja karyawan. Secara bersama-sama variabel keterbukaan terhadap pengalaman, OCB dan budaya organisasi berorientasi karyawan memberikan kontribusi sebesar 49,5\% terhadap kinerja, sedangkan sisanya yaitu $50,5 \%$ berasal dari pengaruh faktor-faktor atau variabel lain diluar dari ketiga variabel independent penelitian tersebut. Berdasarkan hasil analisis tersebut, maka penelitian ini layak untuk dibuat persamaan regresi sebagai berikut:

$$
\begin{aligned}
& Y=a+b 1 X 1+b 2 X 2+b 3 X 3 \\
& Y=6,948+0,197 X_{1}+0,346 X_{2}+0,25 X_{3}
\end{aligned}
$$

Hasil analisis koefisien dari analisis regresi ganda tersebut dapat dijadikan dasar untuk menentukan bobot relatif variabel independen mana yang memberikan sumbangan terpenting pada variabel dependen. Penelitian ini secara spesifik menunjukkan bahwa variabel OCB adalah variabel yang paling dapat memprediksi kinerja karyawan $(\beta=0,535, t=7,555, \quad$ Sig $=$ $0,001)$, diikuti oleh variabel keterbukaan terhadap pengalaman yang menempati urutan berikutnya dalam memprediksi kinerja karyawan $(\beta=0,230, t=3,463$, Sig= $0,001)$. Disisi lain, variabel budaya organisasi berorientasi karyawan tidak secara signifikan dalam memprediksi kinerja karyawan $(\beta=0,042, \quad t=0,691, \quad$ Sig $=0,491)$ [lihat Tabel 6].

Hal ini juga diperkuat dari analisis regresi metode stepwise yang menunjukkan bahwa prediktor yang berperan terhadap kinerja hanya dua, yaitu OCB dan keterbukaan terhadap pengalaman dengan variasi sumbangan masing masing sebesar $45,7 \%$ dan $3,7 \%$.

\section{Diskusi}

Hasil analisis regresi menunjukkan bahwa ketiga prediktor (keterbukaan terhadap pengalaman, OCB dan budaya organisasi berorientasi karyawan) secara bersama-sama memberikan peranan yang signifikan terhadap kinerja karyawan dengan nilai $F$ sebesar 52,971 dan signifikansi 0,001 . Oleh karena itu, dapat dikatakan bahwa hipotesis dalam penelitian ini yang menyebutkan bahwa keterbukaan terhadap pengalaman, dan budaya organisasi berorientasi karyawan merupakan prediktor dari kinerja karyawan diterima.

Ketiga variabel independen tersebut memberi sumbangan sebesar $49,5 \%$ terhadap kinerja karyawan dan sisanya yaitu $50,5 \%$ berasal dari pengaruh faktor-faktor atau variabel lain diluar keterbukaan terhadap pengalaman, OCB dan budaya organisasi berorientasi karyawan. Hasil

Tabel 6

Hasil Analisis Regresi Penelitian-Coefficients

\begin{tabular}{lcccc}
\hline \multicolumn{1}{c}{ Variabel } & $\boldsymbol{B}$ & Beta & $\boldsymbol{t}$ & Sig. \\
\hline (Constant) & 6,948 & & 2,095 &, 038 \\
Keterbukaan terhadap Pengalaman &, 197 &, 230 & 3,463 &, 001 \\
OCB &, 346 &, 535 & 7,555 &, 001 \\
Budaya Organisasi berorientasi Karyawan &, 025 &, 042 &, 691 &, 491 \\
\hline
\end{tabular}


analisis ini dapat diinterpretasikan bahwa 49,5\% kinerja seseorang dapat dijelaskan melalui keterbukaan terhadap pengalaman, OCB dan budaya organisasi berorientasi karyawan. Artinya semakin tinggi nilai keterbukaan terhadap pengalaman, OCB dan budaya organisasi berorientasi karyawan maka kinerja karyawan semakin tinggi. Menurut teori pertukaran sosial perilaku individu dengan individu-individu lainnya di lingkungan saling memengaruhi (Crisp \& Turner, 2007; Myers, 2010). Perilaku individu didasarkan pada perhitungan untung rugi, sehingga apabila perilaku tersebut merugikan dirinya maka tidak ditampilkan.

Dalam konteks kinerja, misalnya seorang karyawan membantu karyawan lainnya menyelesaikan laporan penting, maka karyawan tersebut memberi dirinya sendiri waktu untuk meningkatkan kinerja karyawan lain dan mungkin juga kinerja dirinya sendiri. Selanjutnya karyawan tersebut juga dibantu oleh karyawan yang lainnya untuk meningkatkan kinerjanya sebagai balas budi, hal ini dapat dijelaskan melalui teori social exchange. Norma timbal balik menghendaki karyawan memberikan tanggapan positif kepada perlakuan yang menyenangkan dari pemberi kerja, dengan begitu lingkungan organisasi yang memberi kenyamanan dan keuntungan kepada karyawan dimungkinkan akan menciptakan karyawan yang mendukung kemajuan kinerja organisasi.

Dapat dilihat bahwa secara bersama sama ketiga variabel bebas ini dapat memengaruhi kinerja karyawan, begitu pula bila dilihat secara sendiri-sendiri ternyata variabel OCB adalah variabel yang paling dapat memprediksi kinerja karyawan sebesar $45,7 \%$, diikuti oleh variabel keterbukaan terhadap pengalaman yang menempati urutan berikutnya dalam memprediksi kinerja karyawan sebesar
3,7\%. Disisi lain, variabel budaya organisasi berorientasi karyawan tidak secara signifikan dalam memprediksi kinerja karyawan.

Berdasarkan hal tersebut, dapat diketahui bahwa OCB memiliki pengaruh terbesar dalam memengaruhi kinerja karyawan, yaitu 45,7\%. Hasil ini sesuai dengan beberapa penelitian yang telah menguji hubungan antara OCB dengan kinerja karyawan, Khan dan kawan kawan (2010) menemukan bahwa anteseden OCB memiliki hubungan positif dengan kinerja organisasi di Pakistan, ditambahkan pula bahwa OCB dapat memberikan efek positif terhadap kinerja organisasi misalnya mengurangi ketidakhadiran, turnover, stres psikologis, retensi karyawan serta meningkatkan loyalitas dan kepuasan karyawan dan konsumen (Chahal \& Mehta, 2010). Hubungan antara perilaku OCB dan kinerja dalam tugas merupakan hubungan satu arah, yaitu bahwa perilaku OCB memengaruhi kinerja dalam tugas. Metaanalisis yang dilakukan oleh Hoffman, Blair, Meriac, dan Woehr (2007) menunjukkan bahwa kontribusi dari perilaku OCB terhadap kinerja dalam tugas tersebut sangat kuat, dengan hasil analisis sebesar 0,74 .

Membantu teman sekerja meringankan pekerjaan dan mencegah timbulnya masalah tentang pekerjaan akan dapat meningkatkan kinerja diri sendiri. Karyawan dapat belajar dari pengalaman, pengetahuan dan ketrampilan saat membantu menghadapi permasalahan kerja yang dialami oleh rekan kerjanya sehingga dapat berguna dalam menghadapi permasalahan kerjanya sendiri. Selain itu, keterlibatan individu dalam kegiatan organisasi merupakan bentuk perilaku karyawan untuk mengenal organisasinya. Keterlibatan tersebut nantinya dapat membuat kelekatan tersendiri antara karyawan 
dengan organisasi sehingga menciptakan rasa tanggung jawab dari karyawan untuk memberikan kinerja terbaiknya kepada organisasi. Rasa tanggung jawab tersebut dapat diwujudkan dengan melakukan hal hal yang menguntungkan organisasi dan rasa toleransi pada situasi organisasi yang kurang ideal. Penelitian ini juga mengetahui bahwa dari kelima aspek yang dimiliki oleh OCB (altruism, courtesy, sportsmanship, civic virtue dan conscientiousness), aspek courtesy paling dapat memprediksi kinerja karyawan, disusul oleh aspek altruism dan aspek civic virtue.

Variabel keterbukaan terhadap pengalaman juga memengaruhi kinerja karyawan sebesar 3,7\%. Hal ini sesuai dengan penelitian sebelumnya yang menyebutkan bahwa variabel keterbukaan terhadap pengalaman secara signifikan berkaitan dengan semua dimensi kinerja (Rose, dkk., 2010). Bing dan Lounsbury (2000) dalam penelitiannya pada perusahaan manufaktur di Jepang juga membuktikan bahwa keterbukaan terhadap pengalaman dapat memprediksi prestasi kerja. Selain itu terdapat hubungan unik antara kedua variabel tersebut dengan kemampuan kognitif dan empat konstruk kepribadian Big Five yang lain. Individu dengan keterbukaan terhadap pengalaman yang tinggi menyukai proses belajar yang terus menerus (London \& Smither, 1999), suka berbagi pengetahuan (Cabrera, Collins, \& Salgado, 2006), memiliki motivasi belajar (Major, Turner \& Fletcher, 2006) dan lebih proaktif (Fuller \& Marler, 2009) sehingga lebih dapat menyesuaikan diri dalam mengatasi perubahan organisasional pada konteks yang dinamis. Hal ini pada gilirannya akan memfasilitasi individu untuk memenuhi standar kinerja dan harapan, baik dalam aspek kinerja pekerjaan yang teknis (yaitu, kinerja tugas) maupun non- teknis (misalnya, kontekstual dan penugasan khusus).

Individu dengan keterbukaan terhadap pengalaman yang tinggi merupakan pribadi yang sangat terbuka cenderung kreatif, ingin tahu, berani mengambil risiko, fleksibel dalam menyerap informasi dan sensitif terhadap hal-hal yang bersifat seni (McCrae \& Costa, 2003; Robbins \& Judge, 2008). Selain itu, mereka juga mampu beradaptasi (LePine, Colquitt, \& Erez, 2000), mampu mengatasi perubahan dan memiliki toleransi terhadap ambiguitas (Judge, Thoreson, Pucik, \& Welbourne, 1999). Kemampuan individu dalam berimajinasi dan mengembangkan pikiran yang rumit serta peka terhadap hal-hal yang berhubungan dengan seni dan keindahan membentuk sikap kreatif individu dalam menunjukkan hasil kerjanya. Kepekaan tersebut dimungkinkan akan memberikan unsur-unsur yang berbeda dan indah pada hasil kerjanya sehingga akan lebih bervariasi dan menghindari adanya kebosanan saat melakukan tugas yang berulang-ulang.

Selain itu, rasa ingin tau yang tinggi, keterbukaan terhadap ide-ide baru serta kemampuan seseorang untuk selalu siap menguji kembali nilai-nilai yang ada di lingkungannya dimungkinkan akan memberikan pemikiran tentang konsep-konsep yang lebih terbuka dan luas. Hal itu akan membentuk sikap kritis dan terbuka terhadap pemahaman-pemahaman baru serta mampu bekerja dengan lebih efektif dan efisien. Penelitian ini juga dapat memberikan informasi bahwa diantara keenam aspek yang dimiliki oleh keterbukaan terhadap pengalaman yaitu ideas, fantasy, aesthetics, actions, feelings dan values, aspek aesthetics memberi pengaruh terbesar terhadap kinerja karyawan, dilanjutkan oleh aspek values dan fantasy. 
Disisi lain, dalam penelitian ini juga diketahui bahwa variabel budaya organisasi berorientasi karyawan tidak dapat secara signifikan memprediksi kinerja karyawan $\quad(\beta=0,042, \quad t=0,691, \quad$ Sig $=0,491)$ apabila tidak bersama-sama dengan $\mathrm{OCB}$ dan keterbukaan terhadap pengalaman. Hasil ini mengindikasikan bahwa organisasi yang mengembangkan budaya berorientasi terhadap karyawan tidak serta merta akan meningkatkan kinerja karyawan. Meskipun begitu, penelitian sebelumnya telah membuktikan adanya hubungan signifikan dan positif antara budaya organisasi dengan kinerja karyawan (Prasetyo, 2009; Soedjono, 2005). Tahir dan kawan-kawan (2011) menemukan hubungan antara organisasi pembelajar dengan kinerja karyawan, dan Widyarini (2011) juga mengemukakan bahwa terdapat hubungan antara budaya organisasi sistem terbuka terhadap kinerja tugas.

Berdasarkan hal tersebut dan mengingat OCB dan keterbukaan terhadap pengalaman adalah prediktor bagi kinerja karyawan, maka diperlukan penelitian lebih lanjut untuk mengetahui budaya organisasi yang seperti apa yang dapat mendukung dan memberi peluang bagi karyawan untuk mengembangkan sikap OCB dan kepribadian keterbukaan terhadap pengalaman, seperti misalnya budaya organisasi berorientasi hasil atau budaya organisasi inovatif.

Selain itu penelitian yang dilakukan ini memiliki beberapa kelemahan yaitu: (1) Penelitian ini menggunakan penilaian diri sendiri dalam mengukur kinerja karyawan sehingga rentan terhadap respon bias. Oleh karena itu, dalam penelitian selanjutnya dapat disempurnakan dengan penilaian kinerja dari atasan atau rekan kerja (360 derajat) untuk menghasilkan penelitian yang lebih objektif. (2) Alat ukur dalam penelitian ini perlu diperbaiki kembali terkait dengan validitas konstruknya terutama pada aspek interpersonal relationship dengan aspek atruism dan courtesy, dan (3) Alat ukur yang digunakan dalam penelitian ini masih memiliki aitem aitem pertanyaan yang mengandung social desirability dan penafsiran ganda, sehingga memungkinkan adanya bias terhadap jawaban.

\section{Kesimpulan}

Berdasarkan hasil penelitian dan pembahasan yang telah dilakukan, dapat disimpulkan bahwa keterbukaan terhadap pengalaman, OCB dan budaya organisasi berorientasi karyawan merupakan prediktor dari variabel kinerja karyawan dan secara bersama sama memberikan kontribusi sebesar 49,5\%. Artinya semakin tinggi nilai keterbukaan terhadap pengalaman, OCB dan budaya organisasi berorientasi karyawan maka kinerja karyawan semakin tinggi. Variabel OCB merupakan variabel yang paling kuat memprediksi kinerja karyawan kemudian variabel keterbukaan terhadap pengalaman menempati urutan selanjutnya dalam memengaruhi kinerja karyawan secara signifikan. Perilaku membantu yang dilakukan oleh karyawan dapat memberi pembelajaran kepada karyawan tersebut dan berguna ketika dihadapkan pada permasalahan kerjanya nanti. Selain itu, perilaku tersebut juga dapat membuat kelekatan tersendiri antara karyawan dengan organisasi sehingga menciptakan rasa tanggung jawab dari karyawan untuk memberikan kinerja terbaiknya kepada organisasi. Kepekaan terhadap seni dan keindahan, kesiapan untuk menguji kembali nilai-nilai yang ada dilingkungannya serta kecenderungan seseorang untuk mengembangkan pikiran rumit merupakan sifat-sifat yang dapat memengaruhi kinerja karyawan. Budaya 
organisasi berorientasi karyawan tidak secara signifikan memprediksi kinerja karyawan. Implikasi dalam penelitian ini, mengingat bahwa kedua variabel yaitu OCB dan keterbukaan terhadap pengalaman merupakan prediktor yang signifikan terhadap kinerja karyawan, maka kedua variabel tersebut dapat digunakan sebagai dasar dalam memprediksi karyawan mana yang nantinya akan memberi kinerja terbaiknya pada perusahaan dengan disesuaikan pada kebutuhan masing masing jabatan.

\section{Kepustakaan}

Ali, M., Hayat, K., Sarwat, N., \& Qureshi, J. A. (2011). Job attitudes as a predictor of employee performance: Evidence from public sector of Pakistan. Interdiciplinary Journal of Contemporary Research in Business, 3(4), 631-641.

Anastasi, A., \& Urbina, S. (1997). Psychological Testing (7th Ed.). New Jersey: Prentice Hall.

Barrick, M. R., \& Mount, M. K. (1991). The big personality dimensions and job performance: A meta analysis. Personnel Psychology, 44, 1-26.

Bernadin. H. J., \& Russel, J. E. A. (1998). Human resources management: An experimental approach. New York: McGraw-Hill companies.

Bing, M. N., \& Lounsbury, J. W. (2000). Openness and job performance in US Based Japanese Manufacturing Companies. Journal of Business and Psychology, 14(3), 515-522.

Biswas, S. (2011). Commitment, involvement, and satisfaction as predictors of employee performance. South Asian Journal of Management, 18(2), 92-107.

Bommer, W. H., Dierdorff, E. C., \& Rubin, E. C. (2007). Does prevalence mitigate relevance? The moderating effect of group-level OCB on employee performance. Academy of Management Journal, 50(6), 1481-1494.

Borman, W. C. (1991). Job behavior, performance and effectiveness.In Dunnette, M. D. \& Hough, L. M. (Eds.). Handbook of Industrial and organizational psychology, 2, 271-326. Mumbai: Jaico Publishing House.

Burmana, B. L. (2010). Pengaruh kepribadian tangguh dan konflik peran ganda terhadap kinerja. (Tesis tidak dipublikasikan). Universitas Gadjah Mada, Yogyakarta.

Cabrera, A., Collins, W., \& Salgado, J. (2006). Determinants of individual engagement in knowledge sharing. International Journal of Human Resource Management, 17(2), 245-264.

Cascio, W. F., \& Aguinis, H. (2005). Applied Psychology in Human Resource Management (6 $6^{\text {th }}$ Ed.). New Jersey: Pearson Prentice Hall.

Chahal, H., \& Mehta, S. (2010). Antecedents and consequences of organizational citizenship behavior (OCB): A conceptual framework in reference to health caresector. Journal of Services Research, 10(2), 25-44.

Chen, Z. X., Tsui, A.S., \& Farh, J. L. (2002). Loyalty to supervisor vs. organizational commitment: Relationships to employee performance in China. Journal of occupational and organizational psychology, 75, 339-356.

Coole, D. R. (2003). The effects of citizenship performance, task performance, and rating format on performance judgments (Master tesis). Diunduh dari: http:// scholarcommons.usf.edu/etd/1348

Crisp, R. J., \& Turner, R. N. (2007). Essential Social Psychology. London: Sage Publications. 
Fuller, J. B., \& Marler, L. E. (2009). Change driven by nature: A meta-analytic review of the proactive personality literature. Journal of Vocational Behavior, 75, 329-345.

Griffin, B., \& Hesketh, B. (2004). Why openness to experience is not good predictor of job performance. International Journal of Selection and Assessment, 12(3), 243-251.

Hoffman, B. J., Blair, C.A., Meriac, J. P., \& Woehr, D. J. (2007). Expanding the criterion domain? A Quantitative Review of the OCB Literature. Journal of Applied Psychology, 92(2), 555-566.

Hofstede, G., Hofstede, G. J., \& Minkov, M. (2010). Cultures and organizations: Software of the mind. New York: McGraw Hill.

Human Development Report 2010 team. (2010). Human Development Report 2010. United Nations Development Programme. Diunduh dari: http://hdr. undp.org/sites/default/files/reports/27 0/hdr_2010_en_complete_reprint.pdf

Judge, T. A., Thoresen, C. J., Pucik, V., \& Welbourne, T. M. (1999). Managerial coping with organizational change: A dispositional perspective. Journal of Applied Psychology, 84, 107-122

Kerlinger, F. N. (2000). Foundation of Behavioral Research. New York: Holt, Rinehart \& Winston.

Khan, M. A., Afzal, H., \& Zia. (2010). Correlation between antecedents of organizational citizenship behavior and organizations performance in contemporary Pakistani organizations. Institute of Interdisciplinary Business Research, 1(11), 178-190.

Khan, S., Mukhtar, S., \& Niazi, M. A. K. (2010). Link between organizational justice and employee job performance in the workplace. Interdisciplinary
Journal of Contemporary Research in Business, 2(3), 121-132.

Klehe. U. C., \& Anderson. N. (2007). Working hard and working smart: Motivation and ability during typical and maximum performance. Journal of Applied Psychology, 92, 978-992.

Kreitner, R., \& Kinicki, A. (2010). Organizational Behavior (9th ed.). Burr Ridge, ILL: McGraw-Hill.

LePine, J. A., Colquitt, J. A., \& Erez, A. (2000). Adaptability to changing task contexts: Effects of general cognitive ability, conscientiousness, and openness to experience. Personnel Psycho$\log y, 53,563-593$.

London, M., \& Smither, J. W. (1999). Empowered self-development and continuous learning. Human Resource Management, 38(1), 3-15.

Major, D. A., Turner, J. E., \& Fletcher, T. D. (2006). Personality predictors of motivation to learn: An Examination of the Big Five and Proactive Personality. Journal of Applied Psychology, 91, 927935

Manopol, Y., \& Banirestu, H. (2011). Gaet dulu (talenta terbaik), lalu kembangkan. Swa Sembada, 17(9), 80-84.

McCrae, R. R., \& Costa, P. T. (2003). Personality in adulthood: A five-factor theory perspective. New York: The Guilford press.

Myers, D. G. (2010). Social Psychology (10 Ed.). New York: McGraw-Hill.

Organ, D. W., Podsakoff, P. M., \& MacKenzie, S. B. (2006). Organizational citizenship behavior: Its nature, antecedents, and consequences. London: Sage Publications.

Pentury, G. M. (2010). Kinerja dipengaruhi oleh variable anteseden dan dampaknya pada kepuasan kerja (studi pada 
manajer Bank BRI di Malang). Jurnal Manajemen dan Kewirausahaan, 12(1), 66-75.

Prasetyo, Y. W. (2009). Pengaruh budaya organisasi dan kepuasan kerja terhadap kinerja karyawan pada PT. Jogja TV. (Tesis tidak dipublikasikan), Universitas Gadjah Mada, Yogyakarta.

Rahman, K. S. (2009). Analisis pengaruh locus of control dan kepercayaan terhadap pemberdayaan karyawan dalam peningkatan kinerja karyawan. (Tesis tidak dipublikasikan), Universitas Diponegoro, Semarang.

Robbins, S., \& Judge, T. (2008). Essentials of Organizational Behavior. (9th ed). New Jersey: Prentice Hall

Rose, R. C., Ramalu, S. S., Uli, J., \& Kumar, N. (2010). Expatriate performance in overseas assignments: The role of big five personality. Asian Social Science, 6(9), 104-113.

Schwab, K., Martin, X. S., \& Greenhill, R. (2011). The Global Competitiveness Report 2011-2012. World Economic Forum. Diunduh dari: http://www3. weforum.org/docs/WEF_GCR_Report _2011-12.pdf

Skyrme, P., Wilkinson, L., Abraham, J. D., \& Morrison, J. D. (2005). Using personality to predict outbound call center job performance. Applied HRM Research, 10(2), 89-98.

Soedjono. (2005). Pengaruh budaya organisasi terhadap kinerja organisasi dan kepuasan kerja karyawan pada Terminal Penumpang Umum di Surabaya. Jurnal Manajemen \& Kewirausahaan, $7(1), 22-47$.

Steers, R. M., \& Porter, L. W. (1983). Motivation and work behavior. New York: McGraw-Hill.

Sugiyono. (2011). Statistika untuk penelitian. Alfabeta: Bandung.

Tahir, A., Naeem, H., Sarfraz, N., Javed, A., \& Ali, R. (2011). Organizational learning and employee performance. Interdisciplinary Journal of Contemporary Research in Business, 3(2), 1506-1514.

Thomas, S. Y., Susanna, T., \& O'Hara, L. A. (2006). Relation of employee and manager emotional intelligence to job satisfaction and performance. Journal of Vocational Behavior, 30, 1-13. doi: 10.1016/j.jvb.2005.10.003

Widyarini, N. (2011). Perilaku kewarganegaraorganisasian dan kinerja dalam tugas dengan predictor kepemimpinan spiritual, iklim spiritualitas kerja dan budaya organisasi terbuka. (Disertasi tidak dipublikasikan), Universitas Gadjah Mada, Yogyakarta. 